\title{
Book Review ‘Leadership and School Improvement' (Malay Version)
}

\section{Uqbah Iqbal*}

History Programme, Faculty of Social Sciences and Humanities, UKM 43650 Bangi Selangor, Malaysia

\section{Book Review}

Written by Abdul Ghani Abdullah, this book explores alternative views and perspectives on leadership and school improvement with the aim of giving a contemporary view on how to effectively implement improvements. Among the topics discussed was the changing context of leadership for school improvement preserving, diagnose changes in school improvement, generating school improvement through effective teaching, school improvement through reflective teaching and the development of school improvement study theory.

School is expected to become an institution that works to build a civilization of excellence citizenship with reference to Malaysia as the impact of school leadership which is supported by the National Education Philosophy. Thus, the existing excellence should be nurtured while always striving to make improvements. This is because the current changes taking place in Malaysia makes the process of managing the schools are now more complex. Thus, the success of a school in shaping the young generation that is able to address the challenges of rapid change and development can compensate for mental and emotional well-being can lead to the formation of healthy behavior depends on excellence and leadership in strengthening the image the school staff effectively.

Excellent schools are schools that achieve the best quality and excellence in all relevant areas of academic, personality, management, communication and more important is leadership. The studies showed the effectiveness of school leadership plays an important role in the success of the school. School is not brilliant if the actuator or its leaders cannot afford to drive a culture of excellence. Accordingly, emphasis and call people need to improve the capacity, capabilities and responsibilities of school leadership in generating excellence. Improve the efficiency of micro-schools are seen as the main claim in solving the problem of macro in national and communities levels.

This product can be achieved if school leaders are aware of all the changes and know that this change requires adaptation of various aspects, including responsibilities, workload, increase knowledge should be enhanced and the role that should be played. Unlike leaders like rhetoric, leaders who want continuous improvement of excellence must be involved and know what is happening in the classroom, including the curriculum, teaching strategies, and monitor. Thus, some of the following strategies should be considered by every leader of education, namely to understand the changing context of leadership for Preserving the school improvement, knowing what it was for school improvement, how to post instructional leadership can improve schools, teacher leadership and how to use it to improve the school, methods of diagnosing changes to improve schools, improve the ability of teachers through monitoring and evaluation, generate a school improvement through effective teaching, how to make decisions to improve teaching and learning, improving them through reflective teaching, cultivate research to enhance, develop learning communities in schools, empowering emotional intelligence to improve schools and developing school improvement study theory.

In the world of education that is increasingly complex and challenging, conventional ideas of excellence not only in the principal leadership alone. Thus, this book attempts to explore alternative methods of leadership in the context of improving schools with focused teaching and learning. This book is suitable to be read by the principal, teachers, assistant principals, teachers, principals, subject heads, department heads, teachers, lecturers, education managers, students in higher learning institutions and anyone who wants to achieve school improvement.

In conclusion, the improvements must be made by the school to maintain its excellence. To see that school improvement is successful, the role of the school is very important to realize the strategies outlined above. Strictly speaking, as a professional leader, every principals or headmasters and teachers must be willing to make a radical change in strategy based on an integrated and comprehensive and the emphasis on school improvement. The findings about the school improvement model found suitability study methods and properties of the model to determine the accuracy of the findings. The absence of a strong science foundation to ensure that school improvement can be studied as a phenomenon relatively stable. Advanced research-based approach to school improvement must be through theory of dynamical systems that can unlock the parts that cannot be explained by the researcher knowledge about what makes a school effective. Two approaches can be used, namely using linear analysis with a larger sample, more accurate measurement and design of controlled experiments and using more complex dynamic model associated with the theory. Use the following approaches provide three following effects on the study of improvements to the school, which is studying the long-term effects in terms of admission of students on student achievement, the effects of grouping students and the impact of the adjustment of teacher with student groups, businesses generate research data longitudinally, background the students and the processes that occur at school and lastly, there is the new inspiration for conducting qualitative studies that use specific measurements in order to explain the progress of weakness or school functions and redouble efforts to try and produce the addition and synthesis of qualitative studies.

*Corresponding author: Uqbah lqbal, History Programme, Faculty of Social Sciences and Humanities, UKM 43650 Bangi Selangor, Malaysia, Tel: 60389215354; E-mail: uqbah@siswa.ukm.edu.my

Received May 27, 2016; Accepted July 01, 2016; Published July 10, 2016

Citation: Iqbal U (2016) Book Review 'Leadership and School Improvement' (Malay Version). Bus Eco J 7: 233. doi:10.4172/2151-6219.1000233

Copyright: (C) 2016 Iqbal U. This is an open-access article distributed under the terms of the Creative Commons Attribution License, which permits unrestricted use, distribution, and reproduction in any medium, provided the original author and source are credited. 